\title{
Bioactive micro-constituents of ackee arilli (Blighia sapida K.D. Koenig)
}

\author{
CARLOS D. GRANDE-TOVAR ${ }^{1,2}$, JOHANNES DELGADO-OSPINA ${ }^{1}$, LUISA F. PUERTA ${ }^{1}$, GLORIA C. \\ RODRÍGUEZ ${ }^{1}$, GIAMPIERO SACCHETTI ${ }^{3}$, ANTONELLO PAPARELLA $^{3}$ and CLEMENCIA CHAVES-LÓPEZ ${ }^{3}$ \\ ${ }^{1}$ Grupo de Investigación en Biotecnología, Facultad de Ingeniería, Universidad de San \\ Buenaventura Cali, Carrera 122 \# 6-65, Cali, Valle del Cauca, A. A. 7154, Colombia \\ ${ }^{2}$ Grupo de Investigación de Fotoquímica y Fotobiología, Universidad del Atlántico, \\ Carrera 30 No. 8-49, 081008, Puerto Colombia, Colombia \\ ${ }^{3}$ Faculty of Bioscience and Technology for Food, Agriculture and Environment, \\ University of Teramo, Via R. Balzarini 1, 64100 Teramo, Italy \\ Manuscript received on February 9, 2018; accepted for publications on April 30, 2018
}

\begin{abstract}
How to cite: GRANDE-TOVAR CD, DELGADO-OSPINA J, PUERTA LF, RODRÍGUEZ GC, SACCHETTI G, PAPARELLA A AND CHAVES-LÓPEZ C. 2019. Bioactive micro-constituents of ackee arilli (Blighia sapida K.D. Koenig). An Acad Bras Cienc 91: e20180140. DOI. 10.1590/0001-3765201920180140.
\end{abstract}

\begin{abstract}
Ackee (Blighia sapida K. D. Koenig) is an exotic fruit widely consumed in the Caribbean countries. While there is extensive research on the presence of hypoglycin A, other bioactive compounds have not been studied. We identified and quantified the changes in bioactive molecules (total phenol, ascorbic acid, hypoglycin A, squalene, D: A-Friedooleanan-7-ol, (7.alpha.), and oleic acid), antioxidant potential, and volatile compounds during two stages of ripe. A clear reduction in hypoglycin A, ascorbic acid, and total polyphenols during the maturation process were observed. On the contrary, oleic acid, squalene, and D: A-Friedooleanan-7-ol, (7.alpha.) contents increased about 12, 12, and 13 times, respectively with advancing maturity. These bioactive molecules were positively correlated with radical scavenging (DDPH and ABTS). Solid phase microextraction (SPME) and gas chromatography coupled mass spectrometry (GC/MS) analysis revealed more than 50 compounds with 3-penten-2-one and hexanal as the major compounds in the fully ripe stage. The results suggested that ripe ackee arilli could serve as an appreciable source of natural bioactive micro-constituents.
\end{abstract}

Key words: Antioxidants, Friedooleanan, Hypoglycin, Polyphenols, Squalene.

\section{INTRODUCTION}

Currently, there is a worldwide interest to generate innovative products with high nutritional and functional properties from exotic fruits. Recent studies have shown that frequent consumption of fruits and vegetables is associated with a reduced risk of chronic diseases because of the large

Correspondence to: Johannes Delgado-Ospina

E-mail: jdelgado1@usbcali.edu.co

ORCid: https://orcid.org/0000-0001-8095-4741 amounts of antioxidant compounds they contain including phenolic compounds, carotenoids, anthocyanins and tocopherols (Contreras et al. 2011). In particular, phenols are related to the reduction of different deteriorating processes in the human body through their ability to diminish free radical formation after their consumption (VillaRodríguez et al. 2011).

The ackee fruit (Blighia sapida K.) was introduced from West Africa to Central America in the eighteenth century, and, in Jamaica, it 
became an essential part of Jamaican cuisine and eventually gained status as the national fruit of the country (Atolani et al. 2009). The fruit has a significant role in the local and even regional and international diets and economies (Benkeblia and López 2015). In fact, its popularity as a culinary delicacy has increased internationally; the fruit in brine is mainly exported to Canada, the UK, and the USA, generating high revenues $(\$ 13.971 \mathrm{M}$ US dollars in 2015) for the agricultural sector of the country (STATIN 2017). In some other countries of the region, especially the north side of Colombia, it is used for ornamental purposes showing good adaptation to the edaphic and climate conditions.

The fruit is pear-shaped and opens spontaneously in three fragments when ripe. The arilli are the cream coloured edible part with a large black seed attached to the end of each piece. Traditional medicine has shown supposed medicinal properties of the ackee arilli which can be used to cure or relieve symptoms like fever, constipation, skin infections, and dysentery (Ekué et al. 2010, Olusegum and Olutomi 2013). Nevertheless, the ackee fruit has some disadvantages since it contains two toxic molecules depending on the maturation stage, hypoglycin A (L- $\alpha$-amino- $\beta$-methylene cyclopropyl propionic acid) and hypoglycin B ( $\gamma$-L-glutamyl- $\alpha$-amino- $\beta$-methylene cyclopropyl propionic acid). Both are present in the seeds of the fruit, but only hypoglycin A occurs in the arilli (Bowen-Forbes and Minott 2011, Gaillard et al. 2011). The concentration of hypoglycin A is high in the green unripe fruit, but declines as the ripening process advance making it edible. Ingestion of unripe fruit can lead to a toxic condition called "Jamaican vomiting disease" (Blake et al. 2006).

On the other hand, it has been suggested that a low residual concentration of hypoglycin in ackees may be useful in the development of new therapies in people with specific diseases. The following administration (four weeks) from 100 to $400 \mathrm{mg} / \mathrm{kg}$ bodyweight of methanolic extract of Blighia sapida leaves reduced blood glucose level at all doses used and prevented oxidative stress and dyslipidemia in alloxan-induced diabetic rats (Oloyede et al. 2014). A great part of the research on the ackee fruit has been focused on the study of hypoglycin A (HGA) and $B$ (HGB), but studies regarding the presence of other phytochemical groups are scarce (Benkeblia and López 2015, Garg and Mitra 1967, Antwi et al. 2009, Dossou et al. 2014). Additionally, little is known about the chemical changes occurring during the ripening process of the fruit. Therefore, the present study focused on the identification of some bioactive micro-constituents in ackee arilli from Colombia and their variations during two different ripening stages.

\section{MATERIALS AND METHODS}

\section{PLANT MATERIAL}

The ackee fruits were randomly collected from trees in Los Farallones National Park (Valle del Cauca, Colombia) and classified into two stages of maturity according to the scale described by Bowen-Forbes and Minott (2011). The fruits were selected according to their appearance, discarding bruised or rotten fruit. Finally, 10 fruits per tree were selected from 20 different trees (Fig.1). The arilli portion was separated from the seeds and lyophilised.

\section{ANTIOXIDANT ACTIVITY}

The extraction procedure described by Pérez et al. (2008) was followed with some modifications: four hundred milligrams $(400 \mathrm{mg})$ of lyophilised ackee arilli were mixed in a vial containing $16 \mathrm{~mL}$ of methanol-water $(1: 1 \mathrm{v} / \mathrm{v})$ with constant stirring for 1 hour. The tubes were centrifuged (2241 $\times$ $\mathrm{g}$ for $15 \mathrm{~min}$ at $25^{\circ} \mathrm{C}$ ), and the supernatant was recovered and filtered (Whatman No. 1 filter). A volume of $16 \mathrm{~mL}$ of an acetone-water solution (7:3 $\mathrm{v} / \mathrm{v}$ ) was added to the residue and was then stirred 


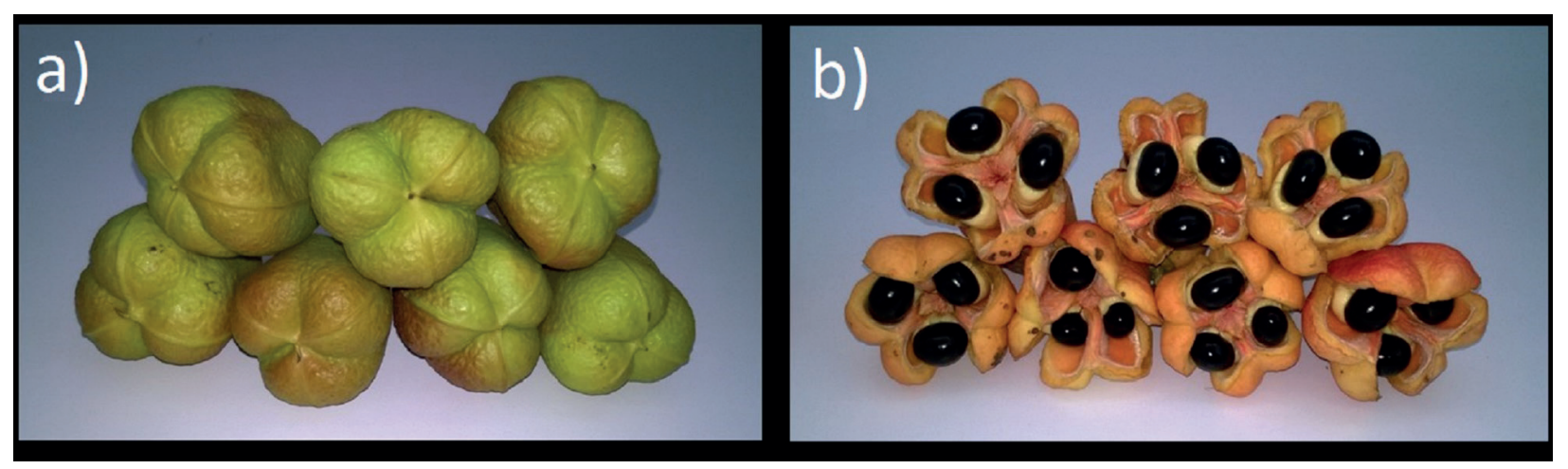

Figure 1 - Ackee fruit at different ripening stages. a) Maturation Stage 1 closed fruit, green pod, and green seed and b) Maturation Stage 5, ripe fruit with exposed arilli, open pods, orange-red, and black seeds.

and centrifuged under the same conditions. The supernatant was recovered again.

\section{ABTS assay}

The radical scavenging activity was measured by the ABTS radical cation discolouration assay described by Re et al. (1999), as $\mu$ mol of Trolox equivalents per gram of fresh sample and was calculated by the ratio of the correlation coefficient of the dose-response curve of the sample and the correlation coefficient of the dose-response curve of the Trolox standard.

\section{DPPH radical scavenging activity assay}

The radical scavenging activity in the different extracts of ackee arilli was measured using the stable free radical DPPH (Brand-Williams et al. 1995). The procedure described by Villa et al. (2011), was followed with some modifications. The radical solution was prepared by mixing $2.5 \mathrm{mg}$ of DPPH radical with $100 \mathrm{~mL}$ of pure methanol and was adjusted to $0.70 \pm 0.02$ absorbance at a wavelength of $515 \mathrm{~nm}$ (Genesys 10uv spectrophotometer). Next, $2.0 \mathrm{~mL}$ of the radical solution was placed in a test tube and $100 \mu \mathrm{L}$ of the diluted extract was added. The mixture was shaken in a vortex and kept in the dark for 30 min until the measurement. The results were expressed in $\mathrm{EC}_{50}$ in $\mathrm{mg} / \mathrm{mL}$ (concentration of antioxidant required to reduce the absorbance of the radical by $50 \%$ ).

\section{POLYPHENOL EXTRACTION AND QUANTIFICATION}

The extraction to determine the polyphenol content (unconjugated + conjugated) in ackee arilli was performed by the method described by Vinson et al. (1998) with some modifications. In brief, $4 \mathrm{~mL}$ of $70 \%$ acetone with $1 \%$ hydrochloric acid were added to $0.2 \mathrm{~g}$ of the sample and the solution was shaken at $200 \mathrm{rpm}$ for $3 \mathrm{~h}$ at room temperature. The mixture was centrifuged at $1089 \mathrm{~g}$ for $30 \mathrm{~min}$ and the supernatant was filled up to $5 \mathrm{~mL}$ with extraction solution. Free polyphenols (unconjugated) were extracted by the same procedure but without hydrochloric acid.

Four millilitres of the supernatants were loaded onto a Strata C18-U cartridge (1g, $6 \mathrm{~mL})$ connected to a vacuum system (Phenomenex Inc., Torrance, CA), previously conditioned with $10 \mathrm{~mL}$ of methanol and followed by $25 \mathrm{~mL}$ of water. After the complete absorption of the sample, the hydrophilic compounds were eluted twice with $4 \mathrm{~mL}$ of $0.1 \mathrm{~N}$ sulphuric acid and discharged. The amphiphilic extracts containing polyphenols were eluted twice with $4 \mathrm{~mL}$ of $70 \%$ acetone and their polyphenol content was quantified after the reaction with Folin-Ciocalteu's reagent according to Singleton 
and Rossi (1965). Extracts (1 mL) were diluted in $50 \mathrm{~mL}$ of bi-distilled water in $100 \mathrm{~mL}$ flasks and mixed with $5.0 \mathrm{~mL}$ of Folin-Ciocalteau's reagent (Sigma, Steinheim, DE) and, after $5 \mathrm{~min}$, with 20 $\mathrm{mL}$ of sodium carbonate (15\%). The flasks were mixed and allowed to sit in the dark for $30 \mathrm{~min}$. The absorbance of the solution was measured at $750 \mathrm{~nm}$ on a Lambda Bio 20 UV/VIS spectrophotometer (Perkin Elmer, Boston, MA) and the results were expressed as mg of gallic acid equivalents (GAE) per gram of dry weight.

The analysis of individual polyphenols in the extracts was carried out by HPLC using the method described by Schieber et al. (2001). The separation of phenolic compounds was carried out using a 1200 Agilent Series HPLC (Agilent Technologies, Milano, Italy) equipped with a G1322 degasser, a G1311A quaternary pump, a G136A Column thermostat, a thermo-autosampler injection system, a column oven, and a diode array detector. The system was controlled with Agilent ChemStation for Windows (Agilent Technologies). An Aqua $5 \mu \mathrm{m} \mathrm{C}_{18}(250 \cdot 4.6 \mathrm{~mm}$ I.D.) from Phenomenex (Torrance, CA, USA) and a security guard C ODS (433.0 mm I.D.) were used. The column temperature was regulated at $25^{\circ} \mathrm{C}$. The mobile phase consisted of $2 \%(\mathrm{v} / \mathrm{v})$ acetic acid in water (eluent $\mathrm{A})$ and $0.5 \%$ acetic acid in water and acetonitrile $(1: 1, \mathrm{v} / \mathrm{v}$; eluent B). The gradient program was: $10 \% \mathrm{~B}$ to $55 \%$ B (50 min), 55\% B to $100 \%$ B (10 min), 100\% $\mathrm{B}$ to $10 \% \mathrm{~B}(5 \mathrm{~min})$. The injection volume for all samples was $10 \mathrm{~mL}$. Simultaneous monitoring was performed at $280 \mathrm{~nm}, 320 \mathrm{~nm}$ and $370 \mathrm{~nm}$ at a flow-rate of $1 \mathrm{~mL} \mathrm{~min}$. Spectra were recorded from 200 to $600 \mathrm{~nm}$.

\section{ORGANIC ACIDS AND SUGAR CONTENT}

Lipids were previously removed from the ackee arilli samples in Soxhlet equipment with ether and the samples were homogenised with $25 \mathrm{~mL}$ of $\mathrm{H}_{2} \mathrm{SO}_{4} 5 \mathrm{mM}$ in an Ultra-Turrax at $15.000 \mathrm{rpm}$ for
30 seconds. The samples were then centrifuged at $4500 \times \mathrm{g}$ for $10 \mathrm{~min}$ at $4^{\circ} \mathrm{C}$ and the supernatants were filtered through a $0.45 \mu \mathrm{m}$ Millipore filter (Millipore Corporation). Organic acids and sugars were analysed with HPLC equipment (Elite Lachrom, Hitachi) coupled with refractive index detector L-2400. Twenty microlitres of the sample were injected in a column (Agilent Hi-Plex H, 300 $\mathrm{mm} \times 6.5 \mathrm{~mm}, 8 \mu \mathrm{m}$ ) using $\mathrm{H}_{2} \mathrm{SO}_{4} 5 \mathrm{mM}$ as mobile phase with an operating flow rate of $0.4 \mathrm{~mL} / \mathrm{min}$ and $65^{\circ} \mathrm{C}$.

\section{DETERMINATION OF THE LIPID FRACTION COMPOSITION}

The lipid Fraction was extracted from lyophilised ackee arilli samples with petroleum ether (bp $60-80^{\circ} \mathrm{C}$, reflux, two hours) in a Soxhlet apparatus and concentrated in a vacuum. The chemical composition of the lipid fraction was determined by Gas Chromatography coupled to Mass Spectrometry (GC-MS) in a Shimadzu model GCMS QP2010 Ultra system, operated in full scan mode (range $35-500 \mathrm{~m} / \mathrm{z}$ ) with a scan speed of 1000 scans $\mathrm{s}^{-1}$, operated in electron impact (EI) mode at $70 \mathrm{eV}$. Separation was carried out on a Restek (Bellefont, PA, U.S.A.) chemically bonded Rtx$5 \mathrm{MS}$ fused-silica capillary column $(30 \mathrm{~m} \times 0.25 \mathrm{~mm}$ i.d. $\times 0.25 \mu \mathrm{m}$ film thickness) with temperature program as follows: beginning at $40^{\circ} \mathrm{C}$ for two minutes, increasing linearly up to $280^{\circ} \mathrm{C}$ in $20 \mathrm{~min}$, and placed on hold for $20 \mathrm{~min}$. The injector was operated at $280^{\circ} \mathrm{C}$ in split mode at 1:20 split ratio. Helium was used as the carrier gas at a flow rate of $1.01 \mathrm{~mL} \mathrm{~min}^{-1}$ and the flow was controlled by the linear velocity at $36.2 \mathrm{~cm} / \mathrm{s}$. Samples $(1.0 \mu \mathrm{L})$ were injected with an AOC-20i+s auto-sampler. The identification of the compounds was established based on their retention index and mass spectra using the NIST11 and WR10 library. 


\section{HYPOGLYCIN A}

Determination of hypoglycin A in the fruit was performed by the method described by Dundee and Minott, using an internal standard calibration method (Dundee and Minott, 2012). The determination was carried out using an HPLC equipment (Elite Lachrom, Hitachi), equipped with a UV detector (254 nm), injected on to a Chromolit RP-18 column $(100 \times 4.6 \mathrm{~mm}$; Guard cartridge: Chromolit RP-18, $5 \times 4.6$ mm Merck, Germany) Hypoglycin A in ackee arilli samples was identified by the comparison of the retention times of its phenylisothiocyanate (PITC) derivative with the derivative of the homologue standard (L-Leucine) and was quantified using the respective calibration curve established for the PITC derivative of the homologue standard.

\section{VOLATILE COMPOUNDS}

The extraction of volatile compounds was carried out by the procedure indicated by Chaves-López et al. (2015) with some modifications: $10 \mathrm{~g}$ of pulp obtained by hand separation from the peel was added to $30 \mathrm{~mL}$ of distilled water and mixed, 10 $\mathrm{mL}$ of this sample was mixed with $2.5 \mathrm{~g}$ of $\mathrm{NaCl}$ and placed in a $50 \mathrm{~mL}$ vial containing a microstirring bar (Chaves-López et al. 2015). Samples were equilibrated for $40 \mathrm{~min}$ at $30^{\circ} \mathrm{C}$ and a solidphase microextraction (SPME) manual device equipped with 50/30 divinylbenzene/ carboxen/ polydimethylsiloxane (DVB/CAR/PDMS) fibre (Supelco, Bellefonte, PA) was used to extract free volatile compounds from the ackee arilli juice. The fibre was conditioned in a GC injector port at $270^{\circ} \mathrm{C}$ for $1 \mathrm{~h}$ before use.

The isolation and identification of the volatile compounds were performed on a Varian (Palo Alto, CA) CP3800 gas chromatograph equipped with a $60 \mathrm{~m} 0.25 \mathrm{~mm}$ i.d. DB-1 $(\mathrm{df}=0.25 \mathrm{~lm}$; J\&W Scientific, Folsom, CA) fused silica capillary column. Analyses were carried out using helium as carrier gas at a column flow of $0.6 \mathrm{~mL} / \mathrm{min}$ in a split ratio of 1:5 with the following program: (i) $80^{\circ} \mathrm{C}$ for $0 \mathrm{~min}$, (ii) temperature ramp rate of $3.0^{\circ} \mathrm{C} /$ min from 80 to $210^{\circ} \mathrm{C}$ and hold for $1 \mathrm{~min}$ followed by, (iii) a temperature ramp rate of $25^{\circ} \mathrm{C} / \mathrm{min}$ from 210 to $300^{\circ} \mathrm{C}$ and hold for $3 \mathrm{~min}$. The temperatures of the injector and detector were 230 and $300^{\circ} \mathrm{C}$, respectively. Several compounds were identified by 3 different analytical methods: (i) retention index (KI), (ii) GC-MS retention times (authentic chemicals), and (iii) mass spectra (authentic chemicals and NIST05 spectral library collection). Identification was considered tentative based only on mass spectrometry data.

\section{STATISTICAL ANALYSIS}

Two batches of 10 samples of unripe and ripe fruits were analysed. The analyses were run in triplicate. Data were expressed as means \pm SD and statistically analysed by the determination of the least significant difference (LSD at $\mathrm{p}<0.05$ ) using SAS (2007) program, version 9.2.

\section{RESULTS AND DISCUSSION}

\section{HYPOGLYCIN A}

Hypoglycin A is an amino acid with the ability to induce hypoglycaemia by inhibiting gluconeogenesis cofactors (CoA and carnitine) that are essential for long-chain fatty acid oxidation. This toxin undergoes dramatic changes in the fruit as described by Gordon and Jackson-Malete (2015). In fact, the content of hypoglycin A in the ackee arilli decreased from $286.0 \pm 31.6 \mathrm{mg} / 100$ $\mathrm{g}$ in the unripe fruit to $43.1 \pm 4.9 \mathrm{mg} / 100 \mathrm{~g}$ in the ripe fruit. Although some researchers suggested that the geographical location of the trees does not significantly influence the HGA content of the fruits $(p>0.05)$, there is evidence of significant differences in HGA content (Table I shows data regarding the presence of HGA in ackee from different countries) because the physiological 
TABLE I

Hypoglycin A content in ackee arilli (Blighia sapida) fruits.

\begin{tabular}{|c|c|c|c|}
\hline Source & $\begin{array}{l}\text { Unripe Ackee fruit } \\
\text { (mg/100 g sample) }\end{array}$ & $\begin{array}{l}\text { Ripe Ackee fruit } \\
\text { (mg/100g sample) }\end{array}$ & Reference \\
\hline Colombia & $286.0 \pm 31.6^{*}$ & $43.1 \pm 4.9 *$ & This study \\
\hline West India & $124.4 \pm 6.7$ & $6.4 \pm 1.1$ & (Golden et al. 2002) \\
\hline Jamaica & $7939 \pm 509$ & $596 \pm 77$ & (Bowen-Forbes and Minott 2011) \\
\hline South Florida & $111 \pm$ N.S & $10 \pm$ N.S & (Brown et al. 1992) \\
\hline Paramaribo (Suriname) & $510 \pm 10$ & N.S & (Gaillard et al. 2011) \\
\hline Burkina Faso & $810 \pm 10$ & N.S & (Gaillard et al. 2011) \\
\hline Jamaica & $920 \pm 10$ & N.S & (Gaillard et al. 2011) \\
\hline
\end{tabular}

*Expressed as means \pm standard deviations of ten samples.

N.S: Not Specified.

conditions of the trees vary according to the place of origin of the fruit and the harvest season (winter or summer) (Bowen-Forbes and Minott 2011, Gaillard et al. 2011, Gordon and Jackson-Malete 2015). However, it is important to highlight that mature ackee arilli on regular-to-medium sized seeds typically contain lower levels of hypoglycin A than mature arilli on very small seeds (Dundee and Minott 2012). It is suggested that lower residual hypoglycin concentrations in ackees may be useful to develop new therapies in people with specific diseases (Oloyede et al. 2014).

\section{SUGAR AND ORGANIC ACID CONTENT}

Ripening of climacteric fruit usually results in the breakdown of starch to sugars to promote sweetness, a decrease the amount of organic acids and phenols to minimise bitterness and astringency and an increase volatile compounds to produce characteristic flavours and aromas. As evidenced by our results, the sugars (fructose, glucose, and sucrose) and organic acids found in the ackee arilli decreased with the maturation state (Table II). These results are in accordance with researchers which reported that total sugars increased during the first four stages of the ackee ripening process and decreased during the last ripening stage (Emanuel and Benkeblia 2011). In this context, fruits with low sugar content (lower than 1\%) are fruits with low carbohydrate content and therefore less sweet flavour. In addition to the changes in sugar concentration during the ackee ripening stages, researchers reported changes in three shortchain fructooligosaccharides identified as 1-kestose (1F-b-D-fructofuranosyl sucrose), nystose (1F(1-bD-fructofuranosyl)2 sucrose) and DP5 (1F(1-b-Dfructo- furanosyl)3 sucrose) (Benkeblia and López 2015).

The organic acid content found in the fruit corresponds to the presence of ascorbic, citric and succinic acid. Ascorbic acid or vitamin $\mathrm{C}$ is an important water-soluble vitamin present in foods. In particular, the values of ascorbic acid found in the ackee arilli were $128.1 \mathrm{mg}$ A.A/100g. Although this parameter is difficult to compare because the contents are highly variable, depending on parameters such as the state of maturity, harvesting period, and variety, the ackee arilli presented higher values compared to those found in different exotic fruits like purple passion fruit (36.3 mg A.A/100g), guava $(65.8 \mathrm{mg} \mathrm{A} . \mathrm{A} / 100 \mathrm{~g})$, or the sweet gold pineapple cultivar (61.0 mg A.A/100g), and lower when compared with fruits such as the Cortibel guava fruit cultivar (168.36 mg A.A/100g) (Valente et al. 2011, Soares et al. 2007). 
TABLE II

Organic acid and sugar content in Ackee arilli (Blighia sapida) fruits.

\begin{tabular}{lcccccc}
\hline & \multicolumn{2}{c}{ Sugar (g/100g sample) } & \multicolumn{2}{c}{ Organic acid (mg/100 g sample) } \\
\hline Unripe & Saccharose & Glucose & Fructose & Citric acid & Succinic acid & Ascorbic acid \\
Ripe & $1.66 \pm 0.04 \mathrm{a}$ & $0.90 \pm 0.05 \mathrm{a}$ & $1.33 \pm 0.07 \mathrm{a}$ & $135.0 \pm 8.1 \mathrm{a}$ & $107.7 \pm 4.5 \mathrm{a}$ & $128.1 \pm 4.2 \mathrm{a}$ \\
\hline
\end{tabular}

Results are expressed as means \pm standard deviations of ten samples. Data expressed as fresh weight. Different letters in the same column indicate significant differences $(\mathrm{p}<0.05)$.

\section{LIPIDS}

The fatty acid profile of the fruit is important because it has implications in health and in the stability of the oil. The total lipids in the ackee arilli increased during the ripening process. In fact, while unripe fruits showed only $2.20 \% \mathrm{~d}$.w, the ripe ones showed values of $33.51 \%$ d.w content. These values are higher than those previously reported 28.34\% and 20.02\% (Machel et al. 2013, Oladiji et al. 2009), but lower than those reported 55.8\% and 46.2\% (Goldson et al. 2014, Mitchikpe 2007). These differences could be attributed to the variable ecological conditions including temperature, humidity, soil, etc., as well as the harvest time and ackee varieties.

The fatty acid percentages present in ackee arilli are shown in Table III. The major oil components in the ackee arilli sampled in this study corresponded to oleic acid (C18:1) (63.45\%) followed by palmitic acid (16:0) (21.35\%) and stearic acid (18:0) (3.51\%) in oil. Studies conducted in ripe ackee arilli from Jamaica reported that palmitic, stearic, and linoleic (18:1) acids were the predominant fatty acids (Odutuga et al. 1992). The same authors suggested that the presence of sunlight during the opening of the fruits increased the lipid content. Also, other researchers noted that ackee oil of Nigeria is rich in behenic, palmitoleic, oleic, gadoleic, erucic, and 9, 12-eicosanoic acids (Oladiji et al. 2009). On the other hand, it was reported that the major acid in the arilli from Jamaica was oleic acid ( $\Delta 9$-cis-oleic acid, an omega n-9) (Emanuel et al. 2013). A diet with high contents of oleic acid (polyunsaturated fatty acid) has been estimated to reduce the risk of suffering coronary heart disease, and to reduce the risk factors for cardiovascular disease such as those related to thrombogenesis, in vitro LDL oxidative susceptibility, and insulin sensitivity (LopezHuertas 2010).

It is important to acknowledge the presence of two important terpenes in the lipid fraction of Colombian ackee arilli: D:A-Friedooleanan-7-ol, (7.alpha.), and squalene (317 \pm 29 and $448 \pm 28$ mg/100 g Ackee, respectively). To our knowledge, this is the first time that these two compounds are reported in ackee arilli. The squalene, a functional lipid, is highly unsaturated hydrocarbon with antioxidant activity that contributes to the reduction of cholesterol, triglyceride levels in serum, and protects against a variety of cancers (Xiao et al. 2016). In addition, squalene has many physiological functions, such as the promotion of superoxide dismutase activity in vivo, enhancement of immune responses and membrane stabilising properties (Bhattacharjee and Singhal 2003, Ko et al. 2002). However, since squalene is an intermediate in endogenous cholesterol synthesis, it has been suggested that it can lead to an increase in cholesterol, which translates to a greater risk for the development of atherosclerosis (Salvo et al. 2017).

Squalene is produced by both animals and plants as a biochemical intermediate. In particular, it is present in high quantities in Amaranthus cruentus (6000-8000 mg/100 g) (Popa et al. 2015), in the brazil nut $(13.8 \mathrm{mg} / 100 \mathrm{~g}$ oil) (Ryan et al. 2009), in Pistacia vera L. (up to $21.8 \mathrm{mg} / 100 \mathrm{~g}$ ) 
TABLE III

Contents lipids in Ackee arilli (Blighia sapida) fruits.

\begin{tabular}{lcc}
\hline \multicolumn{1}{c}{ Name } & Unripe & Ripe \\
\hline Fatty acid & $\mathrm{g} / 100 \mathrm{~g}$ & $\mathrm{~g} / 100 \mathrm{~g}$ \\
Palmitic acid (C16:0) & $0.108 \pm 0.005 \mathrm{~b}$ & $1.397 \pm 0.043 \mathrm{a}$ \\
Oleic acid (C18:1) & $0.344 \pm 0.015 \mathrm{~b}$ & $4.152 \pm 0.164 \mathrm{a}$ \\
Stearic acid (C18:0) & $0.021 \pm 0.002 \mathrm{~b}$ & $0.230 \pm 0.025 \mathrm{a}$ \\
Triterpenes & $\mathrm{mg} / 100 \mathrm{~g}$ & $\mathrm{mg} / 100 \mathrm{~g}$ \\
D:A-Friedooleanan-7-ol, (7.alpha.)- & $24 \pm 3 \mathrm{~b}$ & $317 \pm 29 \mathrm{a}$ \\
Squalene & $36 \pm 5 \mathrm{~b}$ & $448 \pm 28 \mathrm{a}$ \\
\hline
\end{tabular}

Results are expressed as means \pm standard deviations of ten samples. Data expressed as fresh weight of ackee arilli. Different letters in the same row indicate significant differences $(\mathrm{p}<0.05)$.

and in Prunus armeniaca L. kernel oils (12.6-43.9 $\mathrm{mg} / 100 \mathrm{~g}$ of oil) (Salvo et al. 2017, Rudzińska et al. 2017). Several studies suggested that the content of these compounds is significantly affected by the variety among the species and different climate conditions (Salvo et al. 2017, Rudzińska et al. 2017). On the other hand, researchers found that squalene can be used to treat $S$. aureus infections, but we found no evidence of inhibitory activity against $S$. aureus of ackee extracts in vitro (SriCharan-Bindu et al. 2015).

D:A-Friedooleanan-7-ol, (7.alpha.) is poorly known, however, it is reported that friedelane-type triterpenes might have potent anti-diabetic activity as suppressors of hepatic glucose production in insulin-resistant states (Ardiles et al. 2012). To our knowledge, this is the first report of the presence of D:A-Friedooleanan-7-ol, (7.alpha.) and squalene in ackee fruit.

\section{PHENOLIC CONTENT}

The phenolic content of fully ripe fruits was about 6-fold lower than the unripe with $1.5 \mathrm{mg} \mathrm{GAE} \mathrm{g}^{-1}{ }_{\text {d.w }}$. and $2.1 \mathrm{mg} \mathrm{GAE} \mathrm{g}^{-1}$ d.w. of free and total polyphenols, respectively (Table IV). These values are slightly lower than those reported for apples using the same extraction solvent (Sacchetti et al. 2008). Since ripe ackee shows lower moisture content than that of

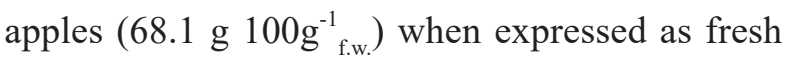

weight, the total polyphenol content is higher than that of apples ( $0.67 \mathrm{mg} \mathrm{GAE}^{-1}{ }_{\text {f.w. }}$ ), but this data only allows ackee to be classified as a fruit with low polyphenol content (Vinson et al. 2001).

When calculated based on total polyphenols data, the percentage of conjugation of polyphenols is about $30 \%$ and is lower than that of apples, which is about 50\% (Vinson et al. 2001). Previous research reported that the level of total phenolic compounds is somewhat higher in the arilli of unripe ackee fruits, but decreases by $30 \%$ during the ripening process. The level of total phenolic compounds ranged from $10.59 \mathrm{mg} \mathrm{g}^{-1}$ fresh weight at the unripe stage 1 to $7.38 \mathrm{mg} \mathrm{g}^{-1}$ fresh weight at the ripe stage 5 (Emanuel and Benkeblia 2011).

Polyphenols in Ackee were also determined by HPLC analysis, and the most abundant ones (in terms of peak intensity) were catechin, epicatechin, and phloridzin which was found in trace amounts. Upon ripening, the abundance of catechin and epicatechin decreased, whilst the content of phloridzin increased. The percentage of conjugation of catechins in ripe ackee arilli is about $30 \%$, similar to that of apples, whilst phloridzin shows a percentage of conjugation of $46 \%$.

Catechin and epicatechin are polyphenols commonly found in tropical fruits (such as cacao) and other common fruits such as apple, plum, and grapevine. On the contrary, phloridzin 
TABLE IV

Total polyphenol and single polyphenol content of unripe and fully ripe ackee fruits.

\begin{tabular}{|c|c|c|c|c|c|c|c|}
\hline \multirow[b]{3}{*}{ Method } & & \multicolumn{6}{|c|}{ Polyphenols } \\
\hline & & \multicolumn{3}{|c|}{ Unripe } & \multicolumn{3}{|c|}{ Ripe } \\
\hline & & Free & Conjugated & Total & Free & Conjugated & Total \\
\hline \multirow{2}{*}{$\begin{array}{l}\text { Singleton and } \\
\text { Rossi (1965) }\end{array}$} & GAE & $8.50 \pm 0.09 \mathrm{a}$ & $3.27 \pm 0.03 \mathrm{a}$ & $11.78 \pm 0.09 \mathrm{a}$ & $1.46 \pm 0.01 \mathrm{~b}$ & $0.65 \pm 0.01 b$ & $2.11 \pm 0.02 \mathrm{~b}$ \\
\hline & \%_Conjugation & & $27.8 \%$ & & & $30.8 \%$ & \\
\hline \multirow{5}{*}{$\begin{array}{l}\text { Schieber et al. } \\
\qquad(2001)\end{array}$} & $(+)$ catechin & $12.8 \pm 0.1 \mathrm{a}$ & $3.77 \pm 0.04 \mathrm{a}$ & $16.6 \pm 0.1 \mathrm{a}$ & $0.150 \pm 0.002 b$ & $0.075 \pm 0.001 b$ & $0.225 \pm 0.003 b$ \\
\hline & (-) epicatechin & $3.60 \pm 0.04 \mathrm{a}$ & $1.32 \pm 0.01 \mathrm{a}$ & $4.92 \pm 0.05 \mathrm{a}$ & $0.351 \pm 0.004 b$ & $0.174 \pm 0.002 b$ & $0.525 \pm 0.005 b$ \\
\hline & Phloridzin & $0.084 \pm 0.001 \mathrm{~b}$ & $0.058 \pm 0.001 \mathrm{~b}$ & $0.142 \pm 0.003 b$ & $0.125 \pm 0.001 \mathrm{a}$ & $0.105 \pm 0.001 \mathrm{a}$ & $0.230 \pm 0.001 \mathrm{a}$ \\
\hline & Total & $16.5 \pm 0.1 \mathrm{a}$ & $5.15 \pm 0.01 \mathrm{a}$ & $21.7 \pm 0.1 \mathrm{a}$ & $0.63 \pm 0.01 b$ & $0.35 \pm 0.01 \mathrm{~b}$ & $0.98 \pm 0.03 b$ \\
\hline & \%_Conjugation & & $23.8 \%$ & & & $36.1 \%$ & \\
\hline
\end{tabular}

GAE: gallic acid equivalent. Data expressed as $\mathrm{mg} / \mathrm{g}$ dry weight. Different letters in the same row and parameter indicate significant differences $(\mathrm{p}<0.05)$.

is not a common polyphenol since it is found primarily in apples; closely related species from the Rosaceae family do not contain phloridzin and only trace amounts were reported in strawberry. The abundance of catechin and epicatechin in ackee fruit is interesting from the nutritional point of view since these polyphenols are bioavailable and abundant antioxidants in foods with widely recognised functional properties, such as cacao, chocolate, and tea (Crozier et al. 2012).

\section{ANTIOXIDANT ACTIVITY}

The antioxidant capacity of the ackee arilli measured by ABTS and DPPH methods increased during the ripe process, as reported in Fig. 2, and the values were higher than those reported for other exotic fruits from South America (Contreras et al. 2011, Vasco et al. 2008). This corroborates the findings of Hamzah et al. (2013) who stated that this fruit could be a potential source of natural antioxidants. Previous research has reported that the increase of the antioxidant activity is associated to physiological factors such as maturity, as well as technological factors like storage conditions and processing (Lindley 1998, Heyles and Lugasi 2006). Thus, we can hypothesize that ripe Ackee arilli could serve as a considerable source of natural antioxidants.

During ripe, fruit suffers physiological and biochemical changes, including the biosynthesis and accumulation of pigments, lipids, vitamins, and antioxidants, among others (Villa-Rodríguez et al. 2011, Goulao and Oliveira 2008). There are also other factors that are present in the physiology such as exposure to light and air, and the presence of pathogens, stress and environmental changes. At these stages, the plant raises physical and chemical barriers, such as the development of secondary metabolites or other types of molecules, where the fruit is protected by a defensive reaction that increases the concentration of antioxidant compounds. In this study, we observed that ackee arilli showed considerable amounts of squalene that probably contributed to the antioxidant activity.

\section{VOLATILE COMPOUNDS}

It is well known that the aroma of fruits comes from some components formed during the fruit 

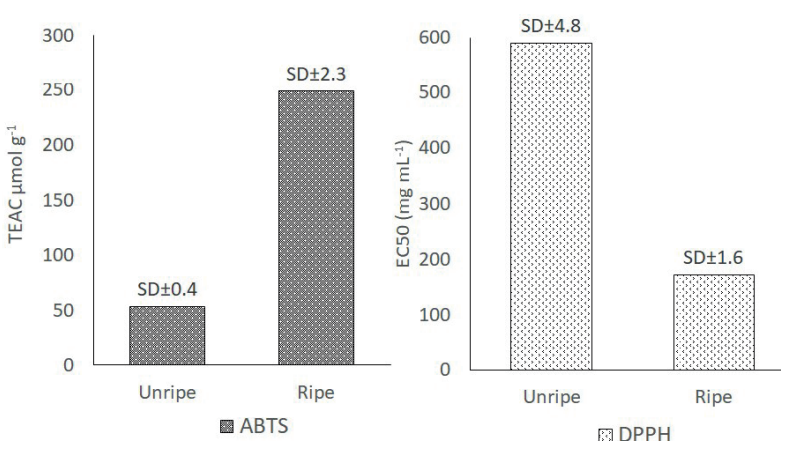

Figure 2 - Antioxidant capacity of the ackee arilli (Blighia sapida) fruit in two maturation stages. ABTS expressed in TEAC (Trolox equivalent antioxidant capacity) as $\mu \mathrm{mol}$ of Trolox equivalents per gram of fresh sample. DPPH expressed in EC50 (concentration of ackee extract required to reduce the absorbance of the radical by $50 \%$ ) in $\mathrm{mg} / \mathrm{mL}$.

ripening process with a low aroma threshold value and high relative content. Many factors affect the volatile composition of fruit, including the degree of maturity and ripening stages, environmental conditions, postharvest handling and storage conditions, as well as the genetic composition of the plant. To the best of our knowledge, information related to the volatile compounds content that contributes to the aroma of the ackee fruit has not been reported yet. The volatile fraction present in the two maturation stages of ackee fruit is reported in Table V. For all the compounds, identification was based on chromatographic peak RI and similarity index (SI) higher than $90 \%$.

The successful identification of 54 compounds during the two stages of maturation yielded different chemical classes of volatile compounds like aldehydes (15), esters (15), carboxylic acids (7), alcohols (6), ketones (4), monoterpenes (3) and alkanes (4). The composition of the volatile fraction changed throughout the ripening stages as evidenced during the present research, where several volatile compounds showed an increase in the relative peak area during ripeness. In particular, there was an increase in ketones, esters, and alkanes. On the contrary, aldehyde and alcohol content decreased during the ripening process.
Among the volatile compounds detected in the unripe ackee arilli fruit, aldehydes correspond to $40 \%$ of the volatile content, followed by alcohols $(19 \%)$, acids $(16 \%)$, and esters $(10 \%)$. In this stage of maturation, hexanal, acetic acid, and benzaldehyde were the most abundant compounds, representing nearly $19 \%, 14 \%$ and $13 \%$ of the volatile fraction, respectively. The contribution of 1-octen 3-ol, dodecane, spiropentanoic acid methyl ester, and 1-hexanol, was also pronounced and ranged between $5 \%$ and $9.6 \%$ of the relative area. Aldehydes, alcohols, and esters may result from enzymatic reactions during fruit ripening. In particular, the presence of C6 aldehydes, alcohols, and esters suggests that the lipoxygenase pathway may be activated during the ripening process (Sansone-Land et al. 2014). Hexanal was found in both maturation stages with a high area percentage. Other C6 compounds were found at different concentrations such as 1-hexanol, 3-hexen-ol, 2-hexenal (E), hexanoic acid-2-penthylethyl ester and hexanoic acid methyl ester. In addition, other products derived from the enzymatic degradation of fatty acids like heptanal, octanal, 3-penten-2-one and 2-heptanone were present.

In the ripe stage, aldehydes were the most abundant compounds with $25 \%$, followed by ketones, acids, and esters with $20 \%, 17 \%$, and $15 \%$, respectively. The volatile fraction was dominated by 3 -penten-2-one (14.95\%), which is usually described to have a sharp, acetone-like and fruity odor, hexanal (13.51\%), that could be correlated with the characteristic odour of unripe fruits, dodecane $(7.1 \%)$ and n-hexadecanoic acid $(6 \%)$, that confer waxy notes, acetophenone $(5.6 \%)$ which provides aromatic notes described as sweet flowers, and nonaldehyde (5\%).

The compounds 3-penten-2-one, n-propyl acetate, 2-butanone 4hydroxy-3-methyl, 2-butenal2-methyl (E), 2-heptanal and gamma terpinene were present only in the fully ripe stage of fruits, contributing to the overall aroma of ripe ackee 
TABLE V

Volatile fraction composition in two maturation stages of ackee fruits (expressed as peak area \%).

\begin{tabular}{|c|c|c|c|}
\hline Compound & KI (Exp) & Unripe & Ripe \\
\hline \multicolumn{4}{|l|}{ Alcohols } \\
\hline pentanol & 2088 & $3.94 \pm 0.21 \mathrm{a}$ & $0.40 \pm 0.03 \mathrm{~b}$ \\
\hline 3-hexen-ol & 847 & $0.67 \pm 0.04$ & n.d \\
\hline 1-hexanol & 841 & $9.20 \pm 0.70 \mathrm{a}$ & $2.59 \pm 0.52 b$ \\
\hline 1-heptanol & 951 & $0.10 \pm 0.03 \mathrm{a}$ & $0.07 \pm 0.03 \mathrm{a}$ \\
\hline 1-3-octen-ol & 963 & $5.08 \pm 0.18 \mathrm{a}$ & $0.28 \pm 0.04 \mathrm{~b}$ \\
\hline 1-octanol & 1052 & $0.31 \pm 0.02 \mathrm{a}$ & $1.44 \pm 0.25 b$ \\
\hline \multicolumn{4}{|l|}{ Esters } \\
\hline formic acid allyl ester & 586 & $0.03 \pm 0.002$ & n.d \\
\hline Butyl acetate & 804.9 & $0.32 \pm 0.03$ & n.d \\
\hline n-propyl acetate & 686 & n.d & $0.43 \pm 0.05$ \\
\hline spiropentanoic acid methyl ester & 842 & $6.98 \pm 0.61$ & n.d \\
\hline butanoic acid-3-methyl ester & 1041 & $0.75 \pm 0.04 \mathrm{a}$ & $0.19 \pm 0.03 b$ \\
\hline 2-propenoic acid, 3-phenyl methyl ester (E) & 1350 & $0.01 \pm 0.002 \mathrm{a}$ & $1.72 \pm 0.56 \mathrm{~b}$ \\
\hline octanoic acid methyl buthyl ester & 1430 & $0.03 \pm 0.004 \mathrm{a}$ & $4.16 \pm 1.02 b$ \\
\hline oxalic acid hexadecyl 2-phenyl ester & & $0.03 \pm 0.001 \mathrm{a}$ & $0.19 \pm 0.01 b$ \\
\hline ictanoic acid hexyl ester & 1571 & $0.04 \pm 0.002 \mathrm{a}$ & $0.23 \pm 0.11 b$ \\
\hline diethyl phalato & 1543 & $0.31 \pm 0.03 \mathrm{a}$ & $1.12 \pm 0.13 b$ \\
\hline hexanoic acid-2-penthylethyl ester & 1616 & $0.22 \pm 0.03 \mathrm{a}$ & $1.23 \pm 0.08 \mathrm{~b}$ \\
\hline isopropyl miristate & 1836 & $0.06 \pm 0.01$ & n.d \\
\hline octanoic acid-2-pentyl ester & 1814 & $0.84 \pm 0.04 \mathrm{a}$ & $3.18 \pm 0.31 b$ \\
\hline hexanoic acid methyl ester & 1909 & $0.49 \pm 0.03 \mathrm{a}$ & $2.84 \pm 0.54 b$ \\
\hline \multicolumn{4}{|l|}{ Acids } \\
\hline formic acid & 543 & $1.17 \pm 0.17 \mathrm{a}$ & $2.35 \pm 0.73 b$ \\
\hline acetic acid & 660 & $13.80 \pm 1.54 \mathrm{a}$ & $3.33 \pm 0.87 \mathrm{~b}$ \\
\hline nonanoic acid & 1263 & $0.36 \pm 0.08 \mathrm{a}$ & $1.28 \pm 0.11 \mathrm{~b}$ \\
\hline dodecanoic acid & 1554 & $0.12 \pm 0.04 \mathrm{a}$ & $0.36 \pm 0.06 \mathrm{~b}$ \\
\hline tetradecanoic acid & 1772 & $0.38 \pm 0.02 \mathrm{a}$ & $0.96 \pm 0.13 b$ \\
\hline n-hexadecanioic acid & 1972 & $0.20 \pm 0.07 \mathrm{a}$ & $6.05 \pm 0.71 b$ \\
\hline octadecanoic acid & 2174 & $0.91 \pm 0.10 \mathrm{a}$ & $3.04 \pm 0.14 \mathrm{~b}$ \\
\hline \multicolumn{4}{|l|}{ Ketones } \\
\hline 3-penten-2-one & 662 & n.d & $14.95 \pm 1.06$ \\
\hline 2-butanone, 4 hydroxy-3-methyl & 832 & n.d & $0.06 \pm 0.02$ \\
\hline 5-hepten-2-one-6-methyl & 960 & $1.16 \pm 0.14 \mathrm{a}$ & $0.18 \pm 0.02 \mathrm{~b}$ \\
\hline Acetofenone & 1052 & $2.20 \pm 0.45 \mathrm{a}$ & $5.64 \pm 0.74 b$ \\
\hline \multicolumn{4}{|l|}{ Aldehydes } \\
\hline butanal-3-methyl & 628 & $0.09 \pm 0.04$ & n.d \\
\hline 2-butenal-2-methyl (E) & 748 & n.d & $0.69 \pm 0.02$ \\
\hline
\end{tabular}


TABLE V (continuation)

\begin{tabular}{lccc}
\hline Compound & KI (Exp) & Unripe & Ripe \\
\hline Hexanal & 771 & $19.86 \pm 1.51 \mathrm{a}$ & $13.52 \pm 1.54 \mathrm{~b}$ \\
2-hexenal (E) & 838 & $0.66 \pm 0.06$ & n.d \\
Heptanal & 879 & $0.26 \pm 0.03 \mathrm{a}$ & $0.38 \pm 0.07 \mathrm{~b}$ \\
2-heptenal & 927 & n.d & $0.21 \pm 0.05$ \\
Benzaldehyde & 928 & $11.83 \pm 1.18 \mathrm{a}$ & $2.10 \pm 0.35 \mathrm{~b}$ \\
Octanal & 981 & $2.17 \pm 0.32 \mathrm{a}$ & $0.94 \pm 0.20 \mathrm{~b}$ \\
Benzeneacetaldehyde & 1012 & $1.06 \pm 0.19 \mathrm{a}$ & $0.08 \pm 0.01 \mathrm{a}$ \\
2-octenal (E) & & $0.11 \pm 0.03$ & n.d \\
furandicarboxy aldehyde & 1996 & $0.10 \pm 0.03 \mathrm{a}$ & $0.25 \pm 0.06 \mathrm{~b}$ \\
1-nonanalaldehyde & 1128 & $1.80 \pm 0.02 \mathrm{a}$ & $5.96 \pm 0.76 \mathrm{~b}$ \\
Decanal & 1184 & $0.49 \pm 0.26 \mathrm{a}$ & $0.93 \pm 0.18 \mathrm{~b}$ \\
2-undecenal & 1191 & $0.28 \pm 0.04 \mathrm{a}$ & $0.11 \pm 0.02 \mathrm{~b}$ \\
Dodecanal & & $0.25 \pm 0.05$ & $0.41 \pm 0.05 \mathrm{~b}$ \\
Monoterpens & & & \\
o-cynene & 1051 & $1.03 \pm 0.14 \mathrm{a}$ & $1.22 \pm 0.30 \mathrm{a}$ \\
Limonene & & $1.06 \pm 0.19 \mathrm{a}$ & $2.15 \pm 0.51 \mathrm{~b}$ \\
gamma terpinene & & $n . d$ & $0.05 \pm 0.01$ \\
Alkans & & & \\
Decane & & $0.59 \pm 0.13 \mathrm{a}$ & $1.15 \pm 0.37 \mathrm{~b}$ \\
Dodecane & & $5.14 \pm 1.10 \mathrm{a}$ & $7.19 \pm 0.26 \mathrm{~b}$ \\
Tetradecane & & $1.12 \pm 0.20 \mathrm{a}$ & $2.03 \pm 0.68 \mathrm{a}$ \\
Hexadecane & & $0.08 \pm 0.02$ & n.d \\
\hline Resls & & &
\end{tabular}

Results are expressed as mean value \pm standard deviation of five samples.

Different letters in the same row indicate significant differences between unripe and ripe stage $(t$-test, $\mathrm{p}<0.05)$.

n.d: Not detected.

R.T: Retention time.

fruit. However, it is important to underline that no single compound or a simple combination of these compounds has the typical smell of ripe fruit.

\section{CONCLUSION}

The present study represents a contribution to the chemical and functional characterisation of ackee fruit. Although polyphenols are reduced during the ripe stage, ackee arilli could serve as an appreciable source of natural antioxidants like citric acid, squalene, and oleic acid. Thus, ripened ackee fruit can be categorised as a functional food that could compete with other tropical fruits how banana, mango, papaya, passion fruit, or pineapple. In this work, for the first time, we identified and quantified the squalene and D: A-Friedooleanan7-ol, (7.alpha.). In addition, the volatile profile of unripe and ripe arilli was identified.

\section{AUTHOR CONTRIBUTIONS}

Carlos D. Grande-Tovar, Antioxidant activity analysis, research, conceptualisation, writingoriginal draft preparation, and writing-review \& editing. Johannes Delgado-Ospina, Bromatological analysis and hypoglycin content analysis by HPLC, 
research, conceptualisation, writing-original draft preparation, and writing-review \& editing.

Luisa F. Puerta, Antioxidant activity analysis, research, and writing-original draft preparation. Gloria C. Rodríguez, Hypoglycin content analysis by HPLC, conceptualisation

Giampiero Sacchetti, Polyphenol characterisation and quantification. Antonello Paparella GC-MS volatile analysis, writing-review and editing. Clemencia Chaves-López. GC-MS volatile analysis, writing-review, and editing.

\section{REFERENCES}

ANTWI S, MARTEY ONK, DONKOR K AND NII-AYITEY LK. 2009. Anti-diarrhoeal activity of Blighia sapida (Sapindaceae) in rats and mice. J Pharmacol Toxicol 4: 117-125.

ARDILES AE, GONZÁLEZ-RODRÍGUEZ A, NÚÑEZ MJ, PERESTELO NR, PARDO V, JIMÉNEZ IA, VALVERDE AM AND BAZZOCCHI IL. 2012. Studies of naturally occurring friedelane triterpenoids as insulin sensitizers in the treatment type 2 diabetes mellitus. Phytochemistry 84 : 116-124.

ATOLANI O, OLATUNJI G AND FABIYI O. 2009. Blighia sapida; the plant and its hypoglycins an overview. J Sci Res 39: 15-25.

BENKEBLIA N AND LÓPEZ MG. 2015. Saccharides and fructooligosaccharides composition of green and ripe Averrhoa carambola, Blighia sapida and Spondias dulcis fruits. Food Chem 176: 314-318.

BHATTACHARJEE P AND SINGHAL RS. 2003. Extraction of squalene from yeast by supercritical carbon dioxide. World J Microb Biot 19: 605-608.

BLAKE O, BENNINK M AND JACKSON J. 2006. Ackee (Blighia sapida) hypoglycin A toxicity: Dose response assesment in laboratory rats. Food Chem Toxicol 44: 207213.

BOWEN-FORBES CS AND MINOTT DA. 2011. Tracking hypoglycins $\mathrm{A}$ and $\mathrm{B}$ over different maturity stages: implications for detoxification of ackee (Blighia sapida KD Koenig) fruits. J Agr Food Chem 59: 3869-3875.

BRAND-WILLIAMS W, CUVELIER ME AND BERSET C. 1995. Use of a free radical method to evaluate antioxidant activity. LWT-Food Sci Technol 28: 25-30.

BROWN M, BATES RP, MCGOWAN C AND CORNELL JA. 1992. Influence of fruit maturity on the hypoglycin A level in ackee (Blighia sapida). J Food Safety 12: 167-177.

CHAVES-LÓPEZ C, MAZZARRINO G, RODRÍGUEZ A, FERNÁNDEZ-LÓPEZ J, PÉREZ-ÁLVAREZ JA AND
VIUDA-MARTOS M. 2015. Assessment of antioxidant and antibacterial potential of borojo fruit (Borojoa patinoi Cuatrecasas) from the rainforests of South America. Ind Crop Prod 63: 79-86.

CONTRERAS J, CALDERÓN L, GUERRA E AND GARCÍA B. 2011. Antioxidant capacity, phenolic content and vitamin $C$ in pulp, peel and seed from 24 exotic fruits from Colombia. Food Res Int 44: 2047-2053.

CROZIER A, ASHIHARA H AND TOMÁS-BARBÉRAN F (Eds). 2012. Teas, cocoa and coffee: Plant secondary metabolites and health. Chichester, UK: Wiley-Blackwell; 2012.

DOSSOU VM, AGBENORHEVI JK, COMBEY S AND AFIKORYOE S. 2014. Ackee (Blighia sapida) fruit arils: Nutritional, phytochemicals and antioxidant properties. Int J Nutr Food Sci 3: 534-537.

DUNDEE S AND MINOTT D. 2012. Impact of seed size on residual hypoglycin levels in ackee. Food Res Int 47: 306309.

EKUÉ MRM, SINSIN B, EYOG-MATIG O AND FINKELDEY R. 2010. Uses, traditional management, perception of variation and preferences in ackee (Blighia sapida K. D. Koenig) fruit traits in Benin: implications for domestication and conservation. J Ethnobiol Ethnomed 6: 12 .

EMANUEL MA AND BENKEBLIA N. 2011. Ackee fruit (Blighia sapida Konig). In: Yahia EM (Ed), Postharvest biology and technology of tropical and subtropical fruits. Cambrige, UK: Woodhead Publishing; 2011, p. 54-64.

EMANUEL MA, GUTIERREZ-OROZCO F, YAHIA EM AND BENKEBLIA N. 2013. Assessment and profiling of the fatty acids in two ackee fruit (Blighia sapida Köenig) varieties during different ripening stages. J Sci Food Agr 93: 722-726.

GAILLARD Y, CARLIER J, BERSCHT M, MAZOYER C, BEVALOT F, GUITTON J AND FANTON L. 2011. Fatal intoxication due to Ackee (Blighia sapida) in Suriname and French Guyana. GC-MS detection and quantification of hypoglycin- A. Forensic Sci Int 206: e103-e107.

GARG HS AND MITRA CR. 1967. Blighia sapida I. Constituents of the fresh fruit. Planta Med 15: 74-80.

GOLDEN KD, WILLIAMS OJ AND BAILEY-SHAW Y. 2002. High-performance liquid chromatographic analysis of amino acids in ackee fruit with emphasis on the toxic amino acid hypoglycin A. J Chromatogr Sci 40: 441-446.

GOLDSON A, BREMMER D, NELSON K AND MINOTT DA. 2014. Fat profile of jamaican Ackees, oleic acid content and possible health implications. W Indian Med J 63: 9-12.

GORDON A AND JACKSON-MALETE J. 2015. The life cycle of Ackee (Blighia sapida): Environmental and other influences on toxicity. In: Gordon A (Ed). Food safety and quality systems in developing countries: Volume One: 
Export challenges and implementation strategies. 1st ed., Jamaica: André Gordon; 2015, p. 33-46.

GOULAO LF AND OLIVEIRA CM. 2008. Cell wall modifications during fruit ripening: when a fruit is not the fruit. Trends Food Sci Tech 19: 4-25.

HAMZAH RU, EGWIN EC, KABIRU AY AND MUAZU MB. 2013. Phytochemical and in vitro antioxidant properties of the methanolic extract of fruit of Blighia sapida, Vitellaria paradoxa and vitex doniana. Oxid Antioxid Med Sci 2: 215-221.

HEYLES L AND LUGASI A. 2006. Formation of certain compounds having technological and nutriotional importance in tomato fruits during maturation. Acta Aliment 35: 183-193.

KO TF, WENG YM AND CHIOU RYY. 2002. Squalene content and antioxidant activity of Terminalia catappa leaves and seeds. J Agri Food Chem 50: 5343-5348.

LINDLEY MG. 1998. The impact of food processing on antioxidants in vegetable oils, fruits and vegetables. Trends Food Sci Tech 9: 336-340.

LOPEZ-HUERTAS E. 2010. Health effects of oleic acid and long chain omega-3 fatty acids (EPA and DHA) enriched milks. A review of intervention studies. Pharmacol Res 61: 200-207.

MACHEL AE, GUTIERREZ-OROZCO F, YAHIA EM AND BENKEBLIA N. 2013. Assessment and profiling of the fatty acids in two ackee fruit (Blighia sapida Köenig) varieties during different ripening stages. J Sci Food Agr 93: 722-726.

MITCHIKPE CES. 2007. Towards a food-based approach to improve iron and zinc status of rural Beninese children: en-hancing mineral bioavailability from sorghum-based food. PhD Thesis, Wageningen University, Netherlands, 2007.

ODUTUGA AA, ASEMOTA HN, MUSAC I, GOLDEN KD AND KEAN EA. 1992. Fatty acid composition of arilli from ackee fruit (Blighia sapida L.). Jamaican J Sci Technol 3: 30-32.

OLADIJI AT, SHOREMEKUN KL AND YAKUBU MT. 2009. Physicochemical properties of the oil from the fruit of Blighia sapida and toxicological evaluation of the oilbased diet in Wistar rats. J Med Food 12: 1127-1135.

OLOYEDE OB, AJIBOYE TO, ABDUSSALAM AF AND ADELEYE AO. 2014. Blighia sapida leaves halt elevated blood glucose, dyslipidemia and oxidative stress in alloxan-induced diabetic rats. J Ethnopharmacol 157: 309319.

OLUSEGUM J AND OLUTOMI P. 2013. Chemical, phytochemical and antimicrobial screening of extracts of B. sapida for agricultural and medicinal relevances. Nat Sci 11: 12-17.

PÉREZ J, ARRANZ S, TABERNERO M, DÍAZ E, SERRANO J, GOÑI I AND SAURA F. 2008. Updated methology to determine antioxidant capacity in plant food, oils and beverager: Extraction, measurement and expression of results. Food Res Int 41: 274-285.

POPA O, BĂBEANU NE, POPA I, NIȚĂ S AND DINUPÂRVU CE. 2015. Methods for obtaining and determination of squalene from natural sources. BioMed Res Int 2015: 1-16.

RE R, PELLEGRINI N, PROTEGGENETE A, PANNALA A, YANG M AND RICE-EVANS C. 1999. Antioxidant activity applying an improved ABTS radical catión decolorization assay. Free Radical Bio Med 26: 12311237.

RUDZIŃSKA M, GÓRNAŚ P, RACZYK M AND SOLIVEN

A. 2017. Sterols and squalene in apricot (Prunus armeniaca L.) kernel oils: the variety as a key factor. Nat Prod Res 31: 84-88.

RYAN E, GALVIN K, O'CONNOR TP, MAGUIRE AR AND O'BRIEN NM. 2009. Fatty acid profile, tocopherol, squalene and phytosterol content of brazil, pecan, pine, pistachio and cashew nuts. Int J Food Sci Nut 57: 219-228.

SACCHETTIG, COCCIE, PINNAVAIA GG, MASTROCOLA D AND DALLA-ROSA M. 2008. Influence of processing and storage on the antioxidant activity of apple derivatives. Int J Food Sci Technol 43: 797-804.

SALVOA, LATORRE GL, DI STEFANO V, CAPOCCHIANO V, MANGANO V, SAIJA E, PELLIZZERI V, CASALE KE AND DUGO G. 2017. Fast UPLC/PDA determination of squalene in Sicilian P.D.O. pistachio from Bronte: Optimization of oil extraction method and analytical characterization. Food Chem 221: 1631-1636.

SANSONE-LAND A, TAKEOKA GR AND SHOEMAKER CF. 2014. Volatile constituents of commercial imported and domestic black-ripe table olives (Olea europaea). Food Chem 149: 285-295.

SCHIEBER A, KELLER P AND CARLE R. 2001. Determination of phenolic acids and flavonoids of apple and pear by high-performance liquid chromatography. J Chromatogr A 910: 265-273.

SINGLETON VL AND ROSSI JAJR. 1965. Colorimetry of total phenolics with phosphomolybdic-phosphotungstic acid reagents. Am J Enol Viticult 16: 144-158.

SOARES FD, PEREIRA T, MARQUES MOM AND MONTEIRO AR. 2007. Volatile and non-volatile chemical composition of the white guava fruit (Psidium guajava) at different stages of maturity. Food Chem 100: 15-21.

SRI-CHARAN-BINDU B, MISHRA DP AND NARAYAN B. 2015. Inhibition of virulence of Staphylococcus aureus - a food borne pathogen - by squalene, a functional lipid. J Funct Food 18: 224-234.

STATIN. 2017. Statical Institute of Jamaica. Exports of traditional and Non-Traditional Commodities. Available at http://statinja.gov.jm/Trade-Econ\%20Statistics/ 
InternationalMerchandiseTrade/Newtrademore.aspx Accessed April 1, 2017.

VALENTE A, GONÇALVES-ALBUQUERQUE T, SANCHES-SILVA A AND COSTA HS. 2011. Ascorbic acid content in exotic fruits: A contribution to produce quality data for food composition databases. Food Res Int 44: 2237-2242.

VASCO C, RUALES J AND KAMAL-ELDIN A. 2008. Total phenolic compounds and antioxidant capacities of major fruits from Ecuador. Food Chem 111: 816-823.

VILLAJ, MOLINAF, AYALAJ, OLIVAS GAND GONZALEZ G. 2011. Effect of maturity stage on the content of fatty acids and antioxidant activity of 'Hass'avocado. Food Res Int 44: 1231-1237.
VILLA-RODRÍGUEZ J, MOLINA-CORRAL F, AYALAZAVALA F, OLIVAS G AND GÓNZALEZ-AGUILAR G. 2011. Effect of maturity stage on the content of fatty acids and antioxidant activity of 'Hass' avocado. Food Res Int 44: 1231-1237.

VINSON JA, HAO Y, SU X AND ZUBIK L. 1998. Phenol antioxidant quantity and quality in foods: vegetables. J Agr Food Chem 46: 3630-3634.

VINSON JA, SU X, ZUBIK L AND BOSE P. 2001. Phenol antioxidant quantity and quality in foods: fruits. J Agri Food Chem 49: 5315-5321.

XIAO H, YAO Z, PENG Q, NI F, SUN Y, ZHANG CX AND ZHONG ZX. 2016. Extraction of squalene from camellia oil by silver ion complexation. Sep Purif Technol 169: 196-201. 